\title{
PRAKTIK GOVERNANCE PERBANKAN INDONESIA DITINJAU DARI ASPEK RISIKO
}

\author{
Erwin Harinurdin ${ }^{1 *}$,Asti Setiawati ${ }^{1 *}$, Wahyu Nofiantoro ${ }^{1 *}$ \\ ${ }^{'}$ Program Studi Administrasi Keuangan dan Perbankan Program Vokasi Universitas Indonesia
}

\begin{abstract}
ABSTRAK - Kinerja berbasis struktur perbankan Indonesia belum memiliki karakter hidup normal perbankan dan masih sangat ditentukan oleh kebijakan ideologis dan politis dari pemerintah. Pemulihan perbankan dengan menggunakan cara yang sangat protektif, seperti dari pembelian obligasi pemerintah dengan margin terbatas atau penyaluran kredit dan penarikan dana dijamin. Berbagai indikator perbankan seperti rasio Loan to Deposit (LDR) dan struktur dana pihak ketiga yang masih didominasi oleh dana jangka pendek seperti giro dan tabungan menunjukkan bahwa bank belum mampu melaksanakan fungsi utamanya dalam sistem ekonomi, fungsi intermediasi.

Dalam rangka restrukturisasi dan pemulihan industri perbankan nasional, Bank Indonesia telah mengambil beberapa kebijakan yang dianggap perlu. Beberapa kebijakan tersebut meliputi implementasi prinsip-prinsip manajemen risiko (sesuai dengan Bassel Accord) dan prinsip mengenal nasabah. Secara keseluruhan, kebijakan ini disusun dalam program orang tua yang sering dikenal sebagai Arsitektur Perbankan Indonesia (API). API diharapkan menjadi blue print serta acuan bagi struktur industri perbankan Indonesia yang dianggap ideal untuk BI.

Sejumlah pelaku tata perbankan menentukan kinerjanya, seperti regulator, supervisor, pemegang saham, direksi, manajemen, audit internal, auditor eksternal, lembaga pemeringkat dan pemilik dana nasabah. Peran masing-masing berbeda sesuai kedudukan, mekanisme akuntabilitas dan harapan sosial. Tapi artikulasi good governance sebagai penonjolan misi, kapasitas dan hubungan menjadi prasyarat untuk pertumbuhan dan stabilitas.

Metode penelitian yang digunakan adalah deskriptif dengan pendekatan kualitatif. Didasarkan pada hasil penelitian disimpulkan bahwa Praktik governance pada perbankan Indonesia belum dilaksanakan secara optimal.
\end{abstract}

Kata kunci: Bank, Resiko, Governance.

ABSTRACT - Performance -based banking structures Indonesia does not have a normal life characters banking and still largely determined by the ideological and political policies of the government. Banking recovery by using a very protective manner, such as from the purchase of government bonds with limited or margin lending and guaranteed withdrawal. Various indicators such as bank loan-deposit ratio (LDR) and the structure of third-party funds that are still dominated by short-term funds such as checking and savings shows that the bank has not been able to carry out its primary function in the economic system, intermediation.

In the framework of the restructuring and recovery of the national banking industry, Bank Indonesia has taken some of the policies that are considered necessary. Some of these policies include the implementation of the principles of risk management (according to Bassel Accor) and Know Your Customer principles. Overall, the policy is structured in parent programs are often known as the Indonesian Banking Architecture (API). API is expected to be the blue print as well as a reference for the Indonesian banking industry structure that is considered ideal for BI.

Determine the number of actors performing the banking system, such as regulators, supervisors, shareholders, directors, management, internal audit, external auditors, rating agencies and owners of customer funds. The role of each differ according to the position, accountability mechanisms and social expectations. But 
the articulation of good governance as a protrusion of the mission, capacity and relationships to be a prerequisite for growth and stability.

The method used is descriptive qualitative approach. Based on the results of the study concluded that the practice of governance in the Indonesian banking system has not been implemented optimally.

Keywords: Keywords: Banks, Risk, Governance.

\section{PENDAHULUAN}

\section{Latar Belakang}

Perbankan merupakan lembaga keuangan yang mempunyai peranan vital dan strategis dalam pembangunan nasional. Lembaga perbankan merupakan salah satu tulang punggung perekonomian suatu negara, karena memiliki fungsi intermediasi atau sebagai perantara antara pemilik modal (fund supplier) dengan penguna dana (fund user). Di Indonesia jumlah bank cukup banyak yaitu 240 buah bank sebelum dilikuidasi tahap pertama pada tahun1999. Sejak digulirkan Paket Oktober 1988 yang lebih dikenal dengan Pakto 88 mengenai deregulasi bidang perbankan menjamurlah bank-bank, baik bank umum maupun bank perkreditan rakyat. Pakto 88 memberikan kemudahan dalam persyaratan pendirian bank. Perkembangan bank sangat fantastis. Pada tahun 1988 s.d 1994 terdapat 134 bank umum, tahun 1996 s.d. maret 2001 dari 239 bank umum menjadi 162 bank, disusul kemudian bulan Desember 2005 menjadi 131 bank umum. ${ }^{1}$

Pasca Pakto 88 kemudahan pendirian itu antara lain adalah rendahnya modal disetor hanya Rp. 10.000.000.000,- (sepuluh milyar) untuk bank umum dan Rp. 50.000.000,- (lima

\footnotetext{
${ }^{1}$ Bank Indonesia.
}

puluh juta) untuk BPR. Apabila dinilai dari besarnya modal disetor maka sangat sulit bagi bank dengan modal disetor minimum tersebut mampu beroperasi karena harus menanggung biaya operasional yang tinggi dibandingkan dengan pendapatan operasional yang relatif rendah.

Adanya kemudahan pendirian bank bukan berarti peluang untuk mencapai laba tinggi dapat tercapai karena banyak berdiri bank-bank baru. Tetapi pendirian bank dimaksudkan pemerintah untuk memacu pertumbuhan ekonomi khususnya usaha mikro dan menengah, namun justru sebaliknya merupakan bumerang yang menghancurkan perekonomian nasional pada sepuluh tahun kemudian (1998) karena pengelolaan bank-bank yang tidak profesional sehingga pemerintah harus menanggung ratusan milyar rupaih dalam bentuk Bantuan Likuidaitas Bank Indonesia (BLBI) untuk nasabah.

Berbagai tindakan telah dilakukan oleh Pemerintah melalui Bank Indonesia, seperti membantu likuiditas, merekapitulasi, menjamin deposan dan kreditur, memperpanjang operasi kondisi minimal, mengelola aset dan menalangi hutang dalam dan luar negeri. Namun kinerja bank-bank tersebut belum kunjung bersandar pada aktivitas perbankan normal. Bahkan sebagian 
bank mengalami kesulitan mencapai norma kesehatan. ${ }^{2}$ Sementara kebocoran-kebocoran masih terus berlangsung. ${ }^{3}$

Kebijakan dan program yang tidak berkesinambungan secara fungsional atau pengulangan-pengulangan yang sebenarnya tidak memperbaiki keadaan sangat mungkin menyebabkan pemulihan semakin sulit. ${ }^{4}$ Menurut Stiglitz, baik negara maju maupun negara yang sedang bertransisi sering mengambil keputusan berdasarkan pertimbangan idelogis dan politis. Akibatnya, banyak tindakan tidak menyelesaikan masalah kecuali memenuhi kepentingan dan keyakinan penguasa. ${ }^{5}$

Kinerja perbankan Indonesia hingga kini belum berdasarkan struktur kehidupan perbankan yang normal dan masih sangat ditentukan oleh kebijakan ideologis dan politis pemerintah. Perbankan hidup dari rente program pemulihan yang sangat protektif, seperti dari pembelian surat berharga pemerintah dengan margin yang terbatas atau dari kucuran kredit dan penarikan dana yang dijamin. ${ }^{6}$ Berbagai indikator perbankan seperti Loan to Deposit ration (LDR) mencapai $70 \%-80 \%$ per juni 2012 dan struktur dana pihak ketiga yang masih didominasi oleh dana jangka pendek

\footnotetext{
${ }^{2}$ Bank Indonesia, bank umum yang layak oprasi harus memiliki CAR, LDR dan NPL masing-masing $8 \%$, $85 \%$ dan $5 \%$ (PBI No. 31/UPPB/1988).

${ }^{3}$ Eko B Supriyanto, Budaya Kerja Perbankan ; Jalan Lurus Menuju Intregitas (Jakarta : Penerbit Pustaka LP3ES Indonesia, 2006) hal 114-115.

${ }^{4}$ Toni A Prasetiantono et al., Bantuan Likuiditas Bank Indonesia, Jakarta : PT Elexmedia Komputindo, 2000 hal 8

${ }^{5}$ Joseph E Stiglitz, Globalization and Its Discontent (New York: W W Norton \& Company, 2003 hal 10.

${ }^{6}$ Kredit Sektor UMKM dan LPS
}

seperti giro dan tabungan menunjukkan bahwa perbankan belum dapat menjalankan fungsi utamanya dalam sistem perekonomian, yaitu fungsi intermediasi. Namun demikian, seiring dengan program penyehatan perbankan, secara lambat, industri perbankan mulai menunjukkan kinerja yang meningkat dari posisi keterpurukan selama krisis ekonomi, walaupun belum mencapai tingkat kinerja sebelum krisis.

Ada dua pandangan utama terkait kinerja perbankan di Indonesia; Pertama, kondisi buruk perbankan Indonesia diikuti oleh kinerja yang rendah adalah dampak kemerosotan kondisi ekonomi. Faktor ekonomi makro seperti; inflasi, nilai tukar, suku bunga. Kedua, kondisi buruk perbankan Indonesia adalah semata-mata efek menular dari penurunan kondisi kawasan regional. ${ }^{7}$

Namun pengamatan indikator kehatihatian seperti pinjaman terhadap simpanan (LDR), posisi devisa (PDN), GWM dan BMPK dan rasio kecukupan modal (CAR) jauh sebelum krisis menunjukkan, baik penurunan kondisi ekonomi mikro maupun dampak penularan hanya sebagai pemicu hancurnya kinerja perbankan indonesia yang selama ini dikelola secara buruk dan diikuti oleh kinerja yang rendah. ${ }^{8}$ Data empiris tersebut menegaskan bahwa penurunan ekonomi mikro dan dampak penularan sekedar menyingkap betapa buruknya governance perbankan Indonesia selama ini. ${ }^{9}$

\footnotetext{
7 George G Kaufman, Bank Problems : A Global Perspective (Connecticut : jai Press Inc., 199) hal 171.

8 Sebelum tahun 1995 LDR $>110 \%$; PDN $>20 \%$; $\mathrm{GWM}<4 \%$; BMPK $>60 \%$ dan $\mathrm{CAR}<7 \%$.

${ }^{9}$ Eko B Supriyanto, op.cit., hal 9
} 
Kajian penelitian ini merujuk temuan Greuning dan Bratanovic, bahwa sejumlah pelaku governance perbankan menentukan kinerjanya, seperti regulator, pengawas, pemegang saham, direksi, manajemen, pemeriksaan internal, auditor eksternal, pemeringkat dan nasabah pemilik dana. Peranan masing-masing berbeda sesuai kedudukan, mekanisme pertangungjawaban dan ekspektasi sosialnya. Namun artikulasi good governance sebagai penonjolan misi, kapasitas dan relasi menjadi prasyarat bagi pertumbuhan dan stabilitas.

Dalam rangka penyehatan serta pemulihan industri perbankan nasional, Bank Indonesia telah mengambil beberapa kebijakan yang dianggap perlu. Beberapa kebijakan tersebut diantaranya adalah implementasi prinsip manajemen resiko (sesuai dengan Bassel Accord) dan know your customer principles. Secara keseluruhan, berbagai kebijakan tersebut dirangkai dalam satu program induk yang sering dikenal dengan istilah Arsitektur Perbankan Indonesia (API). API diharapkan menjadi blue print sekaligus acuan bagi struktur industri perbankan Indonesia yang dianggap ideal bagi BI.

Dari kacamata persaingan usaha, implementasi berbagai kebijakan BI dalam grand design Arsitektur Perbankan Indonesia (API) cenderung menimbulkan polemik. Upaya untuk menyehatkan atau memulihkan kondisi industri perbankan versi API, nampaknya sama dengan mendorong bank (terutama bank menengah dan kecil) untuk melakukan merger/akuissi. Gelombang merger/akuisisi tersebut disatu sisi dapat meningkatkan efisiensi sekaligus penguatan konsolidasi perbankan, namun di sisi lain dapat mengakibatkan terjadinya pemusatan konsentrasi pangsa pasar pada sekelompok bank tertentu. Disini akan muncul polemik dengan kebijakan dan atau hukum persaingan usaha (UU No. 5 Tahun 1999) yang sangat mewaspadai pemusatan konsentrasi tersebut karena berpotensi menimbulkan berbagai pelanggaran seperti diantaranya penyelahgunaan posisi dominan. ${ }^{10}$

Selanjutnya isu yang terkait dengan struktur pasar, juga terdapat isu persaingan usaha lain dalam industri perbankan yang teridentifikasi. Beberapa isu tersebut antara lain interkasi dan koordinasi yang sangat kuat antar bank dalam menjalankan kegiatan operasionalnya seperti standarisasi penetapan suku bunga, risk based pricing dan struktur biaya. ${ }^{11}$

Menurut Gubernur Bank Indonesia Darmin Nasution (pada saat itu) bahwa suku bunga deposito perbankan nasional masih diatas angka inflasi. Di Asia Tenggara semua bunga deposito selalu lebih rendah dari pada inflasi. Tetapi di Indonesia bunga deposito justru di atas indeks harga konsumen. Indonesia ini pengecualian di Asia Tenggara bahkan di Dunia. ${ }^{12}$

Tingkat inflasi di Filipina 5,5 persen, suku bunga deposito berada dikisaran $3-4$ persen, Sementara di Malaysia dan Thailand,

\footnotetext{
${ }_{10}$ Ariyanto, Taufik., Profil Persiangan Usaha Dalam Industri Perbankan Indonesia, Perbanas Finance \& Banking Journal, Vol. 6 No. 2 Desember 2004; 95-108. ${ }^{11}$ Ibid, hal 96.

12 Nasution, Darmin., Bunga Kredit Tetap Tinggi, Majalah Tempo Edisi 5 - 11 Maret 2012.
} 
dengan inflasi $4-5$ persen, suku bunga deposito $2-3$ persen. Tetapi sebaliknya di Indonesia dengan inflasi $5-6$ persen, bunga deposito masih di atas 6 persen. Tingginya suku bunga deposito itu menjadi salah satu penyebab suku bunga dasar kredit masih tinggi. Sampai saat ini bunga kredit belum turun signifikan meskipun bunga acuan Bank Indonesia sudah turun menjadi 5,75 persen dan bunga Sertifikat Bank Indonesia sekitar 6 persen. Bunga kredit di Indonesia masih 9 13 persen pertahun. Penyebab lain masih tingginya bunga kredit adalah karena "rakusnya" perbankan meraup laba. Laba bank yang meningkat menunjukkan upaya menurunkan biaya dana (seperti deposito) masih belum ditranmisikan pada penurunan bunga kredit. ${ }^{13}$

Sehubungan dengan latar belakang di atas, maka pertanyaan penelitian ini adalah:

a. Bagaimana praktik governance pada perbankan Indonesia?

b. Apa fokus perbaikan kinerja perbankan Indonesiajika dilihat dari aspek risiko?

\section{Metode Penelitian}

Guna mengetahui praktik governance pada perbankan indonesia jika ditinjau dari aspek risiko sesuai dengan butir-butir rumusan masalah, tujuan, maka digunakan pendekatan penelitian menggunakan metode penelitian kualitatif. Menurut Irawan dalam peneltian kualitatif, metodologi yang digunakan memiliki ciri yang unik. Ciri tersebut bermula dari permasalahan penelitian

${ }^{13}$ Ibid, 2012. yang dimulai dari pertanyaan luas dan umum, pengumpulan data yang fleksibel, terbuka dan kualitatif, serta penyimpulan temuan yang bersifat induktif dan tidak digeneralisasikan. ${ }^{14}$

Metode kualitatif juga dipilih karena metode kualitatif dapat memberi rincian yang kompleks tentang fenomena yang sulit diungkapkan oleh metode kuantitatif. ${ }^{15}$ Selain itu metode ini juga dipilih karena memiliki karakateristik yang sama dengan ciri-ciri penelitian kualitatif.

Pendekatan kualitatif tersebut diharapkan dapat memahami fenomena sosial yang diteliti dengan gambaran yang bersifat holistic dengan melaporkan pandanganpandangan secara terperinci dan disusun dalam sebuah latar belakang ilmiah.

Penelitian ini dimaksudkan untuk memahami fenomena sosial yang ada melalui gambaran yang bersifat mendalam dan menyeluruh (holistic). Dengan kata lain penelitian ini dilakukan untuk memahami tindakan sosial yang bermakna. Penelitian ini bertujuan untuk mendapatkan gambaran dan pemahaman yang mendalam mengenai kinerja

14 Irawan, Prasetya,"Logika dan Prosedur Penelitian, pengantar Teori dan Panduan Praktik Penelitian Sosial Bagi mahasiswa dan Peneliti Pemula", Jakarta : STIA LAN Press, 2004 hal 61.

15 Anselm Strauss \& Juliet Corbin, Dasar-dasar Penelitian Kualitatif : Tata Langkah dan Teknik-teknik Teoritisasi Data, terjemahan Muhammad Shodiq \& Imam Muttaqien, Pustaka Pelajar, Yogyakarta, 2003, hal 5 
perbankan indonesia, praktik governance serta pemenuhan aspek-aspek risiko dalam perbankan Indonesia.

Penelitian ini bertujuan untuk memberikan suatu deskripsi atau gambaran tentang suatu keadaan. Sehingga jenis penelitian yang digunakan adalah metode dekriptif kualitatif yang dilakukan pada sistem perbankan Indonesia. Dalam melakukan penelitian ini, pengumpulan data dari dua sumber, yaitu ; studi kepustakaan dan studi dokumenter.

Analisis data kualitatif adalah analisis yang dilakukan terhadap data-data non-angka seperti hasil wawancara atau catatan laporan bacaan dari buku-buku, artikel, dan termasuk non tulisan seperti foto, gambar atau film, dengan tujuan mencari suatu pola umum dalam bentuk diskripsi kata-kata. ${ }^{16}$ Mengacu kepada analisis data kualitatif yang dikemukakan oleh Neuman ${ }^{17}$, maka analisis data yang digunakan dalam penelitian ini adalah analisis data kualitatif dengan metode narrative.

\section{HASIL DAN PEMBAHASAN}

Data penelitian adalah bank umum yang berada di bawah otoritas perbankan Indonesia (nasional), baik sebagai bank Persero, Bank Umum Swasta Nasional (Devisa dan Non Devisa), Bank Pembangunan Daerah, Bank

16 Prasetya Irawan, Logika dan Prosedur Penelitian: Pengantar Teori dan Panduan Praktika Penelitian Sosial bagi Mahasiswa dan Peneliti Pemula, STIA Lan Press, Jakarta, 2004 hal. 99

17 W. Lawrence Nauman, Social Research Methods: Qualitative and Quantitatives approach, Fifth Edition, Allyn and Bacon, Boston, 2003, hal 448-449
Campuran maupun Bank Asing. Adapun komposisi Bank Umum di Indonesia dapat dilihat pada tabel dibawah ini. 
Tabel 1.1

Komposisi Bank Umum

\begin{tabular}{|c|c|c|c|c|c|c|c|}
\hline \multirow{2}{*}{ Kelompok Bank } & \multirow{2}{*}{2006} & \multirow{2}{*}{2007} & \multirow{2}{*}{2008} & \multirow{2}{*}{2009} & \multirow{2}{*}{2010} & \multirow{2}{*}{2011} & 2012 \\
\hline & & & & & & & Jun \\
\hline Bank Persero & 5 & 5 & 5 & 4 & 4 & 4 & 4 \\
\hline Jumlah Kantor & 2.548 & 2.765 & 3.134 & 3.854 & 4.189 & 4.362 & 4.781 \\
\hline BUSN Devisa & 35 & 35 & 32 & 34 & 36 & 36 & 36 \\
\hline Jumlah Kantor & 4.395 & 4.694 & 5.196 & 6.181 & 6.608 & 7.209 & 7.305 \\
\hline BUSN Non Devisa & 36 & 36 & 36 & 31 & 31 & 30 & 30 \\
\hline Jumlah Kantor & 759 & 778 & 875 & 976 & 1.131 & 1.288 & 1.316 \\
\hline BPD & 26 & 26 & 26 & 26 & 26 & 26 & 26 \\
\hline Jumlah Kantor & 1.217 & 1.205 & 1.310 & 1.358 & 1.413 & 1.472 & 1.518 \\
\hline Bank Campuran & 17 & 17 & 15 & 16 & 15 & 14 & 14 \\
\hline Jumlah Kantor & 77 & 96 & 168 & 238 & 263 & 260 & 261 \\
\hline Bank Asing & 11 & 11 & 10 & 10 & 10 & 10 & 10 \\
\hline Jumlah Kantor & 114 & 142 & 185 & 230 & 233 & 206 & 191 \\
\hline Total Jumlah Bank & 130 & 130 & 124 & 121 & 122 & 120 & 120 \\
\hline Total Jumlah Kantor & 9.110 & 9.680 & 10.868 & 12.837 & 13.837 & 14.797 & 15.372 \\
\hline
\end{tabular}

Sumber: Statistik Perbankan Indonesia 2012.

Informasi kinerja dapat dilihat dari laporan keuangan (neraca dan laporan labarugi). Neraca berisi informasi aset, kewajiban dan modal pada suatu waktu. Laporan labarugi berisi informasi mengenai hasil aktivitas bisnis dalam kurun waktu tertentu. Aset bank berupa cadangan (reserves), surat berharga dan kredit (loans). Kewajiban berupa simpanan masyarakat (dana pihak ketiga) dan kewajiban lainnya (non deposits). Selisih nilai aset dan kewajiban adalah kekayaan bersih (net worth) atau modal (capital). Adapun laporan keuangan perbankan Indonesia selama 7 (tujuah) tahun terakhir dapat dilihat pada tabel di bawah ini.

Tabel 1.2

Laporan Keuangan Bank Umum Nasional (dalam miliar rupiah)

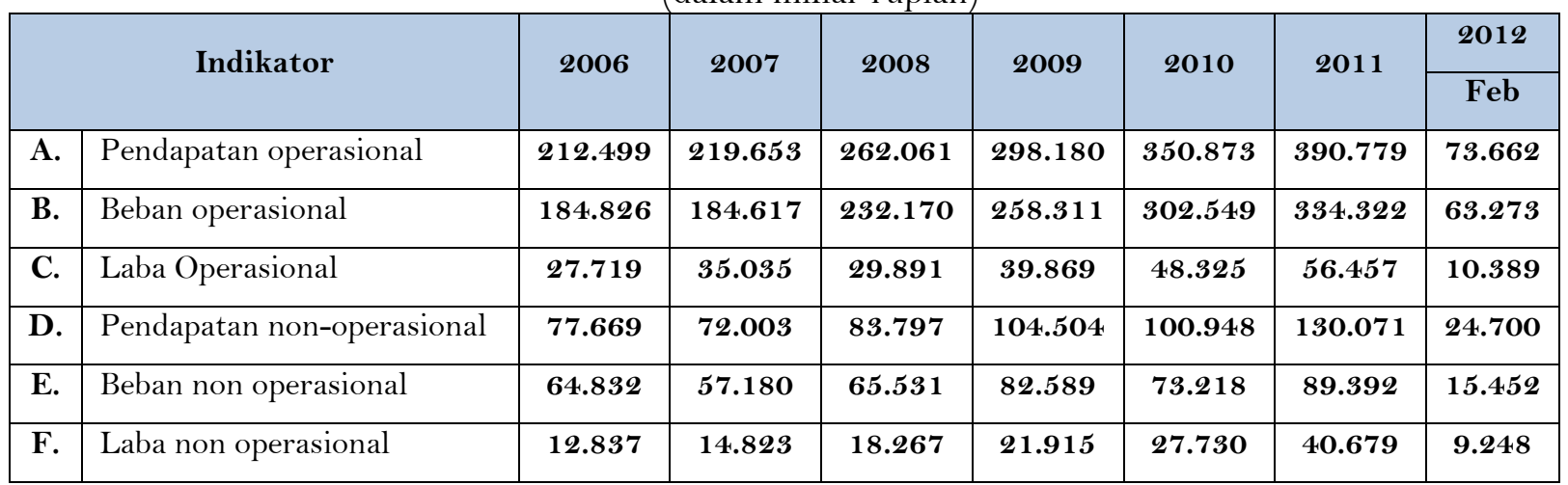




\begin{tabular}{|c|l|c|c|c|c|c|c|c|}
\hline \multicolumn{2}{|c|}{ Indikator } & 2006 & 2007 & 2008 & 2009 & 2010 & 2011 & 2012 \\
\cline { 5 - 9 } & & & & & & Feb \\
\hline G. & Laba tahun berjalan & 40.555 & 49.859 & 48.158 & 61.784 & 76.140 & 97.068 & 19.637 \\
\hline H. & Laba (setelah taksiran pph) & $\mathbf{2 8 . 3 3 4}$ & $\mathbf{3 5 . 0 1 5}$ & $\mathbf{3 0 . 6 0 6}$ & $\mathbf{4 5 . 2 1 5}$ & $\mathbf{5 7 . 3 0 9}$ & 75.077 & 15.513 \\
\hline
\end{tabular}

Sumber: Statistik Perbankan Indonesia Tahun 2012

Pengukuran kinerja Perbankan Indonesia akan menggunakan rasio keuangan untuk mengukur baik buruknya kinerja sebuah bank. Rasio-rasio keuangan bank yang bersangkutan, yang berisi sebelas macam rasio, mulai dari Capital Adequacy Ratio (CAR), hingga Loan to Deposit Ratio (LDR), Net Interest Margin (NIM), Non Performing Loan Net (NPL Net), Return on Assets (ROA), Return on Equity (ROE), dan Cost to Income.

CAR menunjukkan kuat lemahnya struktur permodalan sebuah bank, dimana semakin besar angkanya, maka modal bank yang bersangkutan semakin kuat. NIM menunjukkan besarnya pendapatan bunga bersih (yang sudah dikurangi beban pokok) dibandingkan nilai aset yang menghasilkan bunga tersebut. Semakin besar NIM ini, maka itu berarti bank-nya semakin menguntungkan. ROA dan ROE menunjukkan seberapa besar laba bersih yang dihasilkan bank yang bersangkutan, terhadap nilai aset dan ekuitasnya. Net Profit Growth menunjukkan pertumbuhan laba bersih pada tahun ini dibandingkan tahun lalu. Semakin besar angkanya maka semakin pesat pertumbuhannya. NPL Net menunjukkan rasio kredit macet dibanding total kredit yang disalurkan, dimana semakin kecil tentunya semakin bagus.

Adapun hasil kinerja dan rasio-rasio keuangan perbankan indonesia dapat dilihat pada tabel dibawah ini.

Tabel 1.3

Rasio Kinerja Perbankan Indonesia

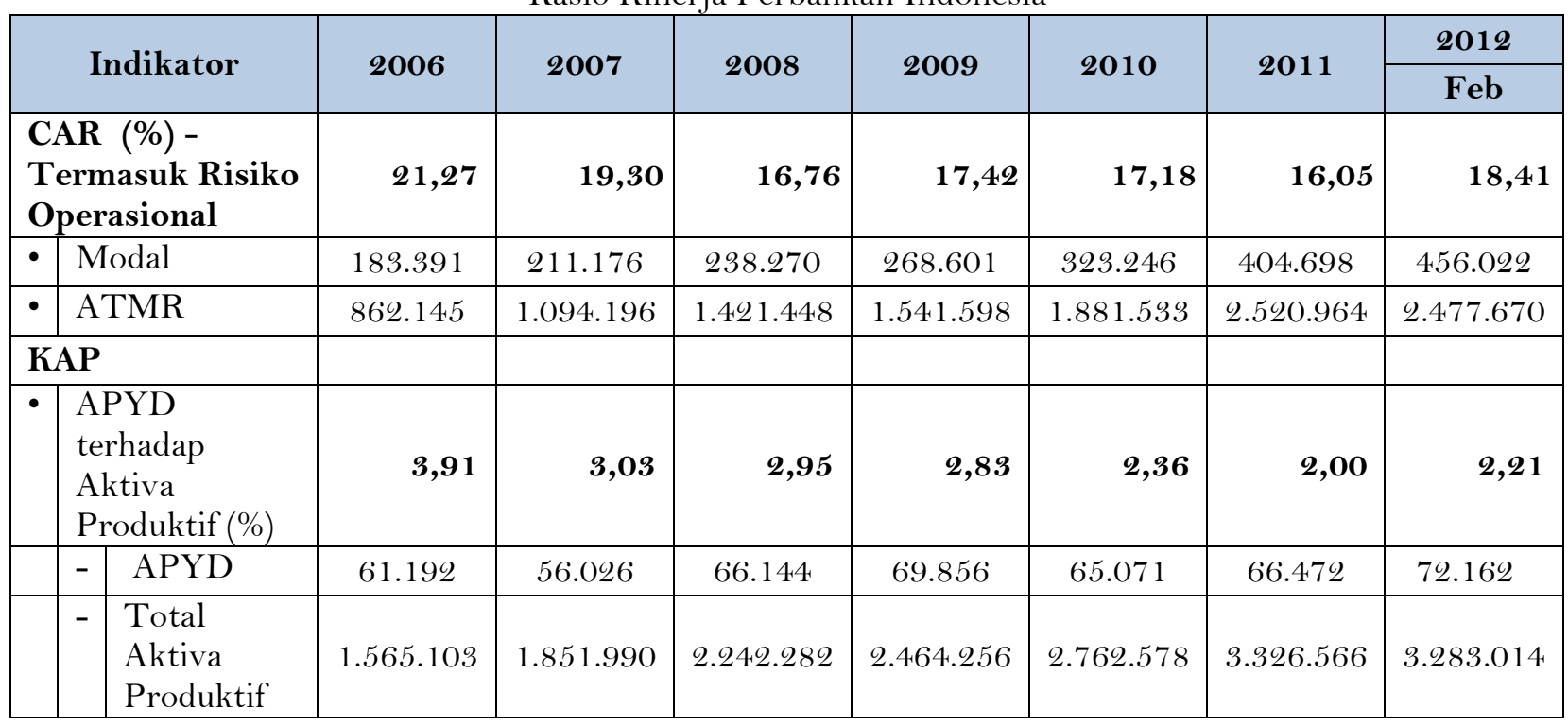




\begin{tabular}{|c|c|c|c|c|c|c|c|c|}
\hline & Indikator & 2006 & 2007 & 2008 & 2009 & 2010 & 2011 & $\begin{array}{c}2012 \\
\text { Feb }\end{array}$ \\
\hline$\bullet$ & $\begin{array}{l}\text { PPAPYD } \\
\text { terhadap } \\
\text { PPAPWD }(\%)\end{array}$ & 126,88 & 193,95 & 168,12 & 157,55 & 130,69 & 114,28 & 104,55 \\
\hline & - PPAPYD & 47.918 & 49.137 & 64.068 & 77.526 & 76.924 & 69.915 & 69.549 \\
\hline & \begin{tabular}{l|l}
- & PPAPWD \\
\end{tabular} & 37.767 & 25.335 & 38.108 & 49.208 & 58.860 & 61.179 & 66.520 \\
\hline \multicolumn{2}{|c|}{ Rentabilitas } & & & & & & & \\
\hline \multirow[t]{3}{*}{$\bullet$} & ROA (\%) & 2,64 & 2,78 & 2,33 & 2,60 & 2,86 & 3,03 & 3,62 \\
\hline & \begin{tabular}{l|l}
- & Laba \\
\end{tabular} & 40.555 & 49.859 & 48.158 & 61.784 & 75.157 & 95.555 & 117.457 \\
\hline & \begin{tabular}{l|l}
- & $\begin{array}{l}\text { Rata-rata } \\
\text { total aset }\end{array}$ \\
\end{tabular} & 1.538 .821 & 1.792 .481 & 2.067 .044 & 2.372 .152 & 2.625 .033 & 3.150 .826 & 3.247 .910 \\
\hline \multirow[t]{3}{*}{$\bullet$} & $\mathrm{BOPO}(\%)$ & 86,98 & 84,05 & 88,59 & 86,63 & 86,14 & 85,42 & 85,96 \\
\hline & \begin{tabular}{l|l}
- & Biaya \\
Operasional
\end{tabular} & 184.826 & 184.617 & 232.170 & 258.311 & 295.422 & 323.825 & 62.036 \\
\hline & \begin{tabular}{l|l}
- & Pendapatan \\
Operasional
\end{tabular} & 212.499 & 219.653 & 262.061 & 298.180 & 342.937 & 379.120 & 72.167 \\
\hline \multicolumn{9}{|c|}{ Likuiditas } \\
\hline$\bullet$ & $\begin{array}{l}\text { Aktiva } \\
\text { terhadap } \\
\text { Pasiva-Likuid } \\
(\%)\end{array}$ & 3,06 & 3,55 & 4,49 & 4,03 & 3,99 & 3,80 & 3,20 \\
\hline \multirow[t]{3}{*}{$\bullet$} & $\operatorname{LDR}(\%)$ & 61,56 & 66,32 & 74,58 & 72,88 & 75,21 & 78,77 & 79,43 \\
\hline & \begin{tabular}{l|l}
- & Kredit \\
\end{tabular} & 792.297 & 1.002 .012 & 1.307 .688 & 1.437 .930 & 1.710 .677 & 2.117 .608 & 2.120 .633 \\
\hline & \begin{tabular}{l|l}
- & Dana Pihak \\
Ketiga
\end{tabular} & 1.287 .102 & 1.510 .834 & 1.753 .292 & 1.973 .042 & 2.274 .489 & 2.688 .364 & 2.669 .949 \\
\hline
\end{tabular}

Sumber : Statistik Perbankan Indonesia Tahun 2012

Analisis kuantitatif akan memberikan gambaran untuk menganalisis kualitatif fungsi governance dan menjelaskan rasionalitas dan gagasan yang mendasarinya.

Regulasi tampak sangat didominasi pendekatan kuantitatif dan ukuran kehatihatian. Perlakuan homogen terhadap semua bank tanpa mempertimbangkan aspek kualitatif (profil risiko, kompetensi dan reputasi). Norma regulasi belum mengadopsi secara penuh prinsip kesepakatan internasional. Sebagian besar ketentuan, seperti BMPK (sektor usaha, debitur dan geografik), LDR, belum mengacu pada norma internasional.
Praktik tradisional memiliki pandangan yang tidak simetris terhadap risiko-hasil. Risiko dipandang sebagai the invisible and intagible uncertainty yang dapat merugikan, sementara hasil merupakan produk sistem pelaporan dengan prinsip yang baku. Praktik tradisional hanya menetapkan eksposur risiko dan memastikan aktivitas menguntungkan.

Praktik modern dilakukan secara terpadu sehingga risiko dapat dieliminasi, dikendalikan dan dialihkan untuk mengurangi dampak buruk bagi kinerja mengingat keputusan menyangkut berbagai aspek risiko yang saling terkait. Praktik modern memandang imbalan sisi lain dari risiko. 
Konsepnya adalah meminimalkan risiko untuk hasil yang maksimal.

Disharmonisasi regulasi menyebabkan ketidakstabilan dan daya saing yang rendah (membuka peluang moral hazard dan memperlemah sistem perbankan domestik). Perbankan yang sehat ternayata memiliki konsep yang luas dan tidak menyangkut permodalan semata. Bank-bank membutuhkan norma yang berlaku umum dan praktik terbaik melalui penerapan disiplin eksternal dan regulasi universal.

Pengawasan sangat fokus pada pemenuhan norma indikatif. Sejumlah rasio kehati-hatian, seperti KPMM, NPL, LDR, BMPK, GWM dan PDN merupakan alat pengawasan yang utama atau kriteria kesehatan dikaitkan dengan penegakan aturan berorientasi kepatuhan. Implikasinya proses pengawasan ditekankan pada pengawasan tidak langsung.

Pengalaman Indonesia menunjukkan bahwa pengawasan yang berfokus pada pencapaian norma indikatif gagal mempertahankan viabilitas keuangan bankbank dan justru mendorong perilaku yang kurang hati-hati. Risiko tidak sepenuhnya tampak pada rasio sehingga bank bertindak melampaui garis. Artikulasinya, pengawasan menuntut pendekatan yang lebih kualitatif dan proses yang sensitif risiko.

Pemilikan bank domestik di Indonesia masih didominasi kelompok keluarga dan negara. Perilaku bank semacam ini cenderung boros karena tujuan utamanya hanya mendukung kepentingan usaha kelompok atau pembangunan ekonomi.
Kepemilikan kelompok keluarga atau negara pada perbankan di Indonesia menghasilkan inefisiensi. Kinerja bank swasta (besar) yang dimiliki dan dikendalikan kelompok keluarga tersubordinasi di bawah kepentingan pemilik. Superioritas manajemen pemilik telah mendorong praktik rente. Sementara, bank pemerintah rentan terhadap penyelahgunaan kekuasaan oleh kelompok berkuasa untuk kepentingan politik. Regulasi sedianya mampu mencegah konsentrasi kekuasaan.

Bankir-bankir sering mengambil risiko yang tidak patut. Bank seharusnya terlibat dalam risiko yang dapat dikelola lebih efisien atau risiko yang sangat khusus terkait dengan keberadaan bank. Penerapan governance di Indonesia menunjukkan bahwa governance internal dan pengelolaan yang lemah menambah postur risiko. Pengambilan risiko lebih berdasarkan selera pasar dan mengabaikan konsep kehati-hatian.

Pengeloaan risiko sedianya merupakan hasil proses bisnis normal yang melekat pada kegiatan sehari-hari pada level operasional, bukan sesuatu yang terpisah dan dikerjakan paruh waktu (tidak komprehensif). Opini eksternal audit terhadap laporan manajemen belum sepenuhnya menggambarkan profil risiko sesungguhnya dan menimbulkan kesenjangan atau keslahan persepsi.

Pemeringkatan masih sebatas pengelolaan data publik. Produknya belum dapat dijadikan basis kalkulasi risiko. Perbankan Indonesia belum mengenal fungsi lembaga pemeringkat sebagaimana di negara- 
negara yang sudah memiliki tradisi pemeringkatan.

Para analsis keuangan gagal memberi pencerahan. Lembaga birokratis sulit diharapkan menghasilkan evaluasi yang memadai. Peranan lembaga pemeringkat, baik lokal maupun global dapat memainkan peranan penting dalam mencermati trend keuangan dan prospek bank-bank individual dan memberikan sinyal (kekuatan-kelemahan) sebelum informasi resmi hasil pengujian otoritas atau tindakan pengawasan.

Nasabah perbankan Indonesia masih mengutamakan keamanan dananya dan cenderung tidak membedakan lembaga keuangan bank dan non bank. Mencari pengetahuan semua faktor risiko dirasakan terlalu mahal dan kompleks bagi nasabah. Hal ini menunjukkan bahwa mereka yang potensial dirugikan tidak memiliki posisi tawar yang memadai.

Masyarakat pemilik dana tampak belum berfungsi sebagai komponen strategis perbaikan. Aspirasi masyarakat dalam bentuk kehati-hatian memilih bank dan tuntutan kualitas layanan yang lebih tinggi sesungguhnya menjadi salah satu sumber tekanan eksternal untuk memperbaiki corporate governance dan mendorong praktik yang sehat.

Dari elemen-elemen governance diatas dapat dilihat bahwa bank-bank belum sepenuhnya melaksanakan governance dalam kerangka risiko-risiko yang universal. Meminimalisir risiko bukan menjadi tujuan utama bank-bank, melainkan menetapkan keuntungan yang sebesar-besarnya. Hal ini dapat dilihat dari suku bunga kredit yang masih tinggi meskipun bank Indonesia sudah beberapa kali menurunkan suku bunga. Besarnya porsi deviden yang harus disetor kepada pemerintah membuktikan bahwa pemilik terlalu rakus dalam mengambil keuntungan. Jika porsi deviden tersebut dikurangi akan dapat meningkatkan ekspansi kredit dan memacu pertumbuhan ekonomi karena akan dijadikan tambahan laba ditahan dan dapat digunakan untuk penyaluran kredit infrastruktur bersuku bunga rendah.

Deviden yang disetorkan pemerintah akan menjadi salah satu unsur penerimaan di APBN. Namun penggunaan APBN Indonesia sering digunakan secara boros, digerogoti mafia anggaran dan dapat digunakan sebagai dana politik terselubung. Sebagai BUMN, Bank-bank tersebut termasuk bank-bank besar yang bisa menjadi penentu atau acuan bagi bank yang lain.

Bankir nasional disebut sebagai pelaku industri paling boros dalam pengeluaran operasional. Indikatornya adalah rasio BOPO yang masih besar. Selain faktor gaji karyawan, biaya promosi juga menjadi salah satu penyebabnya. Menurut Deputi Gubernur Bank Indonesia Halim Alamsyah, di kawasan Asia hanya perbankan Indonesia yang menyediakan hadiah bagi nasabahnya. Hingga saat ini, program-program promosi yang menawarkan hadiah berupa peralatan elektronik, sepeda motor, dan mobil masih gencar dilakukan. Sementara perbankan luar negeri lebih memilih alat promosi seperti sponsorship untuk social events atau turnamen olah raga. 
Lebih jauh, dalam komponen biaya tenaga kerja, remunerasi pejabat eksekutif terutama Dewan Komisaris (Board of Commissioners) dan Dewan Direksi (Board of Directors) mengambil porsi yang signifikan. Remunerasi tersebut mencakup gaji, tunjangan, tantiem, dan fasilitas lain dalam bentuk natura seperti rumah dan kendaraan. Tantiem (bonus) merupakan pembagian keuntungan untuk direksi dan komisaris yang diberikan berdasarkan persentase atau jumlah tertentu dari laba bersih. Selain tantiem, beberapa bank juga masih memberikan opsi saham.

Hasil riset terhadap beberapa bank menunjukan makin kecil aset bank, proporsi pengeluaran untuk BOC dan BOD terhadap total beban tenaga kerja justru makin besar. Hasil tersebut memang belum dapat menggambarkan secara jelas struktur remunerasi di industti perbankan Indonesia. Beberapa bank telah menerapkan sistem remunerasi berbasis kinerja, sementara beberapa bank lainnya tetap menaikan remunerasi meski kinerja bank sedang turun. ${ }^{18}$

Di Indonesia sendiri, hingga saat ini dapat dikatakan belum ada standar kebijakan remunerasi pejabat eksekutif bank yang jelas. Tidak ada ukuran standar batas atas dan batas bawah. Dalam beberapa Laporan Tata Kelola Perusahaan, kebijakan remunerasi bank masih mengacu pada kesepakatan pemegang saham dalam RUPS. Artinya, parameter yang digunakan tiap bank dapat berbeda setiap

${ }_{18}^{18}$ Stabilitas Perbankan edisi April 2011 tahunnya. Tidak adanya batasan standar membuat bank boros menawarkan tingkat remunerasi yang tinggi. Salah satu alasan yang sering mengemuka adalah kelangkaan bankir yang memiliki kapasitas sebagai eksekutif.

Besarnya pos pengeluaran untuk tenaga kerja tersebut mendorong terciptanya rasio BOPO (biaya operasional dan pendapatan operasional) yang tinggi. Mengacu pada statistik, dalam lima tahun terakhir rasio BOPO industri perbankan Indonesia berada pada kisaran 73 persen hingga 97 persen. Rata-rata BOPO dalam kurun waktu tersebut adalah 86,44 persen. Artinya pendapatan Rp1 mesti ditebus dengan pengeluaran Rpo,86.19 Besarnya rasio BOPO tersebut menunjukan masih belum efisiennya industri perbankan nasional.

Industri perbankan yang merupakan "urat nadi" perekonomian masih belum berperan maksimal dalam menggerakan sektor riil. Beberapa kalangan menuding bank di Indonesia sebenarnya belum sepenuh hati dalam mengucurkan kreditnya. Bank masih suka menanamkan dananya pada instrumeninstrumen investasi berisiko rendah seperti SBI dan Obligasi.

Masih tingginya suku bunga disinyalir menjadi salah satu sebab kecilnya penyaluran kredit. Meski suku bunga acuan BI Rate sudah terpangkas signifikan, bank masih bertahan pada level yang cukup tinggi. Dalam lima tahun terakhir rata-rata spread suku bunga rupiah perbankan nasional berada dalam

\footnotetext{
19 (Lihat Tabel 5.2. Rasio BOPO Bank Umum Indonesia) 
kisaran 4,63 persen-6,88 persen, sementara rata-rata spread suku bungadollar AS sebesar 2,41 persen-7,33 persen. Sebagai perbandingan, Net Interest Spread Singapura, Malaysia, dan Vietnam masing-masing pada kisaran 4,90 persen, 3,30 persen, dan 2,83 persen. Per Oktober 2011, Net Interest Margin bank umum di Indonesia mencapai 5,95 persen. Dengan spread yang lebar tersebut, perbankan nasional berhasil membukukan laba tinggi. Return on Assets Ratio dari 80 bank mencapai lebih dari 1,5 persen, dengan rata-rata bank umum mencapai 3,11 persen. Mungkin ini prestasi yang membanggakan, mengeruk untung di negeri sendiri.

\section{KESIMPULAN}

Berdasarkan hasil analisis dan pembahasan dapat disimpulkan bahwa Praktik governance pada perbankan Indonesia belum dilaksanakan dalam kerangka secara optimal. Hal ini dapat dilihat dari regulasi belum mendorong konsistensi tetapi justru menciptakan kesenjangan. Pengawasan yang masih lemah dan bersifat tidak langsung. Kepemilkan masih didominasi oleh kelompok keluarga dan negara. Manajemen belum optimal dalam pengelolaan risiko. Fungsi pemeringkatan yang belum digunakan secara optimal. Fungsi lembaga yang belum berhatihati dengan risiko, khususnya menyangkut reputasi.

Komunitas perbankan Indonesia menggunakan kekuasan secara boros dan terlibat rente yang menguntungkan diri sendiri atau kelompok. Perbankan belum menggunakan penetapan risiko minimal sebagai tujuan utama, melainkan keuntungan yang menjadi tujuan utama. Hal ini mengakibatkan sulitnya penurunan suku bunga kredit dan perkembangan kredit perbankan. Masyarakat perbankan yang terpaku terhadap doktrin, jika Bank Indonesia menurunkan suku bunga acuan maka yang harus segera disesuaikan terlebih dahulu adalah cost bukan revenue.

\section{DAFTAR PUSTAKA}

Anselm Strauss \& Juliet Corbin, Dasar-dasar Penelitian Kualitatif: Tata Langkah dan Teknik-teknik Teoritisasi Data, terjemahan Muhammad Shodiq \& Imam Muttaqien, Pustaka Pelajar, Yogyakarta, 2003, hal 5

Ariyanto, taufik., Profil Persiangan Usaha Dalam Industri Perbankan Indonesia, Perbanas Finance \& Banking Journal, Vol. 6 No. 2 Desember 2004; 95-108.

Bank Indonesia, Bank umum yang layak oprasi harus memiliki CAR, LDR dan NPL masing-masing $8 \%, 85 \%$ dan $5 \%$ (PBI No. 31/UPPB/1988).

Eko B Supriyanto, Budaya Kerja Perbankan ; Jalan Lurus Menuju Intregitas (Jakarta : Penerbit Pustaka LP3ES Indonesia, 2006) hal 114-115. 
George G Kaufman, Bank Problems : A Global Perspective (Connecticut : jai Press Inc., 199) hal 171.

Irawan, Prasetya, Logika dan Prosedur Penelitian, pengantar Teori dan Panduan Praktik Penelitian Sosial Bagi mahasiswa dan Peneliti Pemula, Jakarta : STIA LAN Press, 2004 hal 61.

Joseph E Stiglitz, Globalization and Its Discontent (New York : W W Norton \& Company, 2003 hal 10.

Nasution, Darmin., Bunga Kredit Tetap Tinggi, Majalah Tempo Edisi 5- 11 Maret 2012. Ibid, 2012.

Toni A Prasetiantono et al., Bantuan Likuiditas Bank Indonesia, Jakarta : PT Elexmedia Komputindo, 2000 hal 8

W Lawrence Neuman, Social Research Methods: Qualitative and Quantitative Approach, Fifth Edition, Allyn and Bacon, 2003, hal 448-449. 